\title{
Relation between Necrosis and Rishitin Accumulation in Potato Tuber Slices Treated with Hyphal Wall Components of Phytophthora infestans
}

\author{
Susumu SAKAI*, Noriyuki Doke* and Kohei TomiyAma* \\ 酒井 進*・道家紀志*・冨山宏平* : ジャガイモ疫病菌菌体壁成分処理ジャガイモ \\ 塊茥切断組織に和ける細胞え死とリシチン蓄積との関係
}

Key Words : potato, Phytophthora infestans, rishitin accumulation.

Treatment of plant tissue with hyphal wall components (HWC) is known to induce accumulation of phytoalexins ${ }^{1,2,3,4)}$. In previous studies ${ }^{5,6,7,8,9,13)}$, the present authors reported that rishitin was synthesized in healthy tissue neighbouring the infected lesion, transported into necrotic tissue and accumulated there. Rishitin, remaining in healthy tissue surrounding the necrotic lesion, was supposed to be transformed rapidly to rishitin-M-1, rishitin-M-2 and more hydrophilic unknown compounds in succession, resulting in accumulation of trace amounts of rishitin in the healthy tissue zone ${ }^{8,9,15)}$.

Accordingly, a question raised as to whether HWC of Phytophthora infestans caused necrotic lesion in the tuber tissue, resulting in accumulation of rishitin, or induced this accumulation without causing necrosis.

Tubers of the potato cultivar Rishiri with $\mathrm{R}_{1}$-gene stored in a dark room at $4 \mathrm{C}$ were used. The tubers were sterilized with $1 \%$ sodium hypochlorite, washed with water and then sliced into disks $16 \mathrm{~mm}$ in diameter and $1 \mathrm{~mm}$ thick. The disks were placed in a plastic box at $18 \mathrm{C}$ in dark condition for $20 \mathrm{hr}$. Race 0 and 1 of Phytophthora infestans were cultured in a rye-seed extract medium ${ }^{10)}$. After 2 weeks of incubation, mycelial mats were submitted to HWC extraction according to the method of Lisker and $\mathrm{Ku}^{\mathrm{c}^{3}}$. $\mathrm{HWC}$ was dissolved in distilled water at concentrations of $0.5,1.0$ and $5.0 \mathrm{mg} / \mathrm{ml}$. Fifty $\mu \mathrm{l}$ each of $\mathrm{HWC}$ solution was placed on each disk and incubated for $12,24,36,48,50$ and $72 \mathrm{hr}$. At each incubation intervals, 10 disks were immersed in $30 \mathrm{ml}$ of methanol for $24 \mathrm{hr}$. The methanol extract was sampled and the

\footnotetext{
* Faculty of Agriculture, Nagoya University, Nagoya 464, Japan 名古屋大学農学部

Present address of the first auther: Nisso Institute for Life Science, Nippon Soda Co., Ltd, Oiso, Kanagawa 255, Japan日本曹達秼生物科学研究所
}

1) Albersheim, P. and Valent, B. S. (1978). J. Cell Biol. 78:627-643. 2) Ayers, A., Ebel, J., Valent, B.S. and Albersheim, P. (1976). Plant Physiol. 57: 760-765. 3) Lisker, N. and Kuć, J. (1977). Phytopathology 67: 1356-1359. 4) Anderson, Prouty, A. and Albersheim, P. (1975). Plant Physiol. 56: 286-291. 5) Sato, N. and Tomiyama, K. (1969). Ann. Phytopath. Soc. Japan $35: 1127-1133$. 6) Nakajima, S., Tomiyama, K. and Kinugawa, M. (1975). Ibid. 41:39-55. 7) Tomiyama, K. and Fukaya, M. (1975). Ibid. 41:418420. 8) Ishiguri, Y., Tomiyama, K., Doke, N., Murai, A., Katsui, N., Yagihashi, F. and Masamune, T. (1978). Phytopathology 68:720-725. 9) Sato, K., Ishiguri, Y., Doke, N., Tomiyama, K., Yagihashi, F., Murai A. and Masamune, T. (1978). Phytochemistry 17:1901-1902. 10) Caten, C. E. and Jinks, J. L. (1968). Can. J. Bot. 46: 329-348. 
disks were again immersed in $\mathrm{MeOH}$ for $24 \mathrm{hr}$. Combined $\mathrm{MeOH}$ extract $(50 \mathrm{ml})$ was condenced to syrup in a vacuum, and then the syrup was extracted three times with ethylacetate (EtOAc). After EtOAc was evaporated, rishitin was determined by gas liquid chromatography according to the method of Henfling and $\mathrm{Kuc}^{11}$.

At intervals after treatment with HWC, death of the cells in the surface of the disks treated with HWC was observed under a microscope using the method described previously ${ }^{12}$.

The results obtained from the experiments using $\mathrm{HWC}$ of race 0 are shown in Fig. 1. Experiments were repeated twice with the same results. The mean analytical results are shown in Fig. 1. Rishitin could hardly be detected by GLC in present analytical condition $12 \mathrm{hr}$ after the treatment regardless of the HWC concentration used. At this time ( $12 \mathrm{hr}$ after the treatment), few dead cells were observed. Twenty hr after the treatment, a small amount of rishitin and also a small number of dead cells were found in the disks treated with HWC. After that, rishitin contents and percentages of dead cells in the surface of the disks increased linearly with time. The higher the HWC concentration, the greater the rate of increase in the rishitin amount and also in the percentage of dead cells. The correlation between rishitin contents and percentage of dead cells in the surface of disks was $\mathrm{r}=0.86$ (statistically significant at 0.01) (Fig. 2).

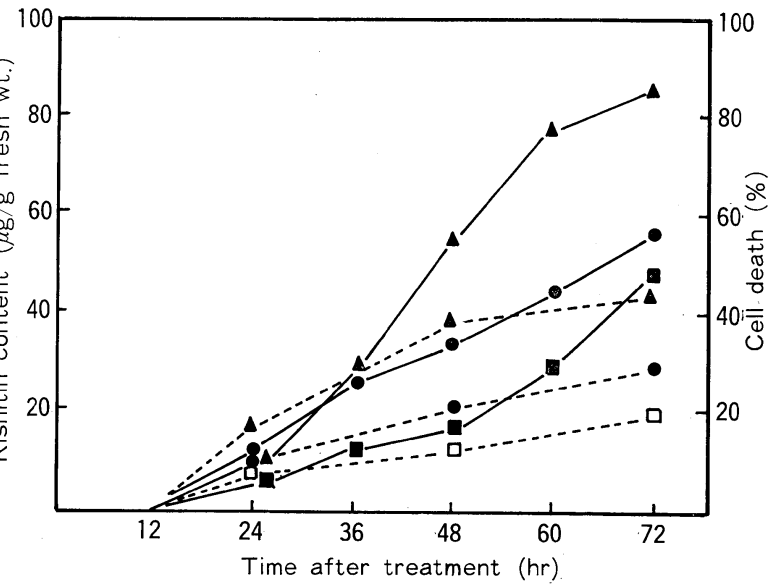

Fig. 1. Time courses of rishitin accumulation and increase in percentage of cell death in potato tuber disks treated with hyphal wall components (HWC) of Phytophthora infestans. The disks were treated with HWC of race 0 at 0.5 (triangle), 1.0 (circle), and 5.0 (square) $\mathrm{mg} / \mathrm{ml} 18 \mathrm{hr}$ after cutting. Rishitin content: filled marks, cell death: open marks.

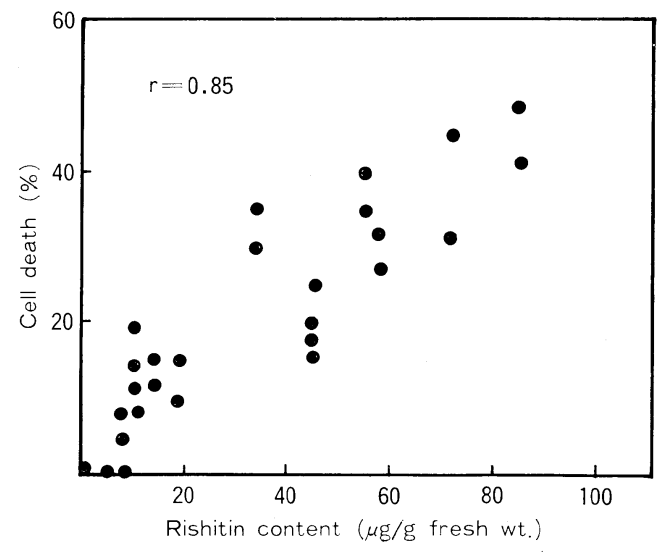

Fig. 2. Relation between rishitin content and percentage of cell death in potato tuber disks treated with hyphal wall components of race 0 or race 1 of Phytophthora infestans $18 \mathrm{hr}$ after cutting.

The same results were obtained in the experiments in which HWC of race 1 was used. These results indicated that a rishitin accumulation could only be chemically detected

11) Henfling, J. W. D. M. and Kuć, J. (1979). Phytopathology 69:609-612. 12) Nozue, M., Tomiyama, K. and Doke, N. (1978). Ibid. $68: 873-876$. 
after dead cells began to appear in the tissue treated with HWC. The increase in percentage of dead cells accompanied with the increase in rishitin accumulation can be explained by our previous findings $\mathrm{s}^{5,6,7,8,9,13)}$ that rishitin is synthesized in metabolically active healthy tissue such as surroundings of infected lesions, very young tissues and so on, but it is rapidly transformed to rishitin-M-1, rishitin-M-2 and more hydrophilic compounds in living cells ${ }^{6,7,8)}$. Rishitin accumulates in the necrotic cells which have no enzymes to transform rishitin.

In the previous study ${ }^{14)}$, it was found that incorporation of radioactivity of acetate$2-\mathrm{C}^{14}$ into rishitin was rather reduced in the cells which contacted HWC directly, but had not yet died. Therefore, the accumulation of rishitin in the dead cells caused by HWC may not be due to synthesis in the cells which contact HWC directly. HWC may cause cell death of the treated tissue, resulting in rishitin accumulation in the dead cells by translocating from the surroundings. It is supposed that physiological changes in the cells which contact HWC directly and are injured may be involved in acceleration of metablic activity in the surrounding cells, resulting in acceleration of the rishitin synthetic pathway in those cells. Further investigation to confirm this assumption is necessary.

The authers are grateful to Messrs. S. Nishibe and Y. Irikura, Hokkaido Agricultural Experimental Station for a generous supply of the experimental materials.

(Received October 7, 1981)

13) Sakai, S., Tomiyama, K. and Doke, N. (1979). Ann. Phytopath. Soc. Japan 45:705-711. 14) Sakai, S., Tomiyama, K. and Doke, N. (1981). Ibid. 47:255-257. 15) Horikawa, T., Tomiyama, K. and Doke, N. (1976). Phytopathology 66: 1186-1191. 